\title{
Virgin Texas: Treponematosis-Associated Periosteal Reaction 6 Millenia in the Past
}

\author{
Bruce M. Rothschild ${ }^{1}$, Christine Rothschild ${ }^{2}$, Glen Doran ${ }^{2}$ \\ ${ }^{1}$ Northeastern Ohio Medical School, Rootstown, USA; \\ ${ }^{2}$ Florida State University, Tallahassee, USA. \\ Email: bmr@ku.edu \\ Received August 21 ${ }^{\text {st }}$, 2011; revised October $7^{\text {th }}$, 2011; accepted October $18^{\text {th }}, 2011$.
}

\begin{abstract}
In bioarchaeology, skeletal biology and paleopathology, periosteal reaction has been variably considered as a non-specific sign of trauma and alternatively as having potentially diagnostic implications. Examination of sixth millennium before present Texas cemeteries falsifies the non-specific trauma hypothesis, while examination of a second millennium before present site reveals a new (at least to Texas) population phenomenon. In contrast to isolated bumps and osteomyelitis, the study of periosteal reaction in early Texas is the study of "virgins," individuals spared the phenomenon that cause such bone alteration. It is only in the second millennium before present that periosteal reaction becomes widespread, both in population penetrance and in extent of skeleton affected. That pattern has previously been documented for the treponematosis yaws, similar to what has been found in other areas of Archaic North America.
\end{abstract}

Keywords: Treponematoses, Yaws, Periosteal Reaction

\section{Introduction}

The tenet of "in vivo veritas" directs that the etiology of attributed phenomena be established by comparison of criteria with those established in validated populations. That is especially important for treponemal disease. Repetition of speculative ideas has in the past achieved prominence in the "collective consciousness" of the field, so much so that it is often overlooked that such "diagnostic criteria” simply represent untested thoughts. Will Rogers stated that it ain't so much what we don't know that gets us into trouble, as what we "know" that ain't so (Spodick, 1975).

The suggestion that periosteal reaction has disease specificity as a population phenomenon is well documented (Rothschild \& Martin, 1993, 2006; Rothschild \& Rothschild, 1996, 1998a). Cook's (1976a-b, 1984) attribution of non-focal periosteal reaction to trauma has been falsified, except in the presence of complicating osteomyelitis or stress fracture (Resnick, 2002; Rothschild \& Martin, 1993, 2006).

Pathology can provide valuable clues to population origins and migrations (Rothschild \& Rogers, 2010). It is therefore essential that pathology be accurately recognized and that its implications be validated. The concept that periosteal reaction is non-specific apparently had it origins in variable skills of examiners (Byers, 1998; Cook, 1998; Katzenberg, 1992; Powell \& Eisenberg, 1998; Rose, 1985; Rothschild \& Rothschild, 1995b) and preconceived notions as to its significance/derivation (Goodman et al., 1988) and as to the nature of disease (Buikstra \& Cook, 1980; Cook, 1976a-b, 1998; Powell \& Eisenberg, 1998; Power, 1992; Sanford et al., 1998; Spirov, 1991). The speculation that current distribution of disease implies climatic restriction was never actually tested by those involved in its promulgation (Cook, 1998; Powell \& Cook, 2005; Powell \& Eisenberg, 1998). Their attribution of periosteal reaction to trauma has impeded progress in our understanding of peoples and the disease with which they were afflicted. The work described herein further evidences the fallacy of the trauma hypothesis and removes periosteal reaction as simply a stress marker (Cook, 1998; Sanford et al., 1998). In vivo veritas replaces speculation with a new opportunity for clarification of the anthropologic record.

Treponemal disease, in the form of Yaws, has been documented on the basis of periosteal reaction in much of North America (Rothschild \& Rothschild, 1994, 1998, 2000; Rothschild et al., 1995a). This pattern extends from the Cascade mountains to the east coast of Florida, dating from 8 - 9 millennia before present (bp). Its distribution has been contiguous across North America east of the Cascade mountains, with several notable exceptions (Rothschild \& Rothschild, 1998, 2000): The Northwest territories of Canada were unaffected, as was Ontario prior to invasion by the Iroquois. This caveat must considered for some areas (e.g., Saskatchewan, Nebraska, Iowa, Kansas, Oklahoma) which have not had skeleton populations available for analysis in the post-1987 time period for which data-based criteria have been available (Rothschild \& Rothschild, 1995).

Texas skeletal populations were therefore examined for evidence of periosteal reaction.

\section{Materials and Methods}

The Texas and other North American sites delineated in Table 1 were chosen to assess the population frequency and nature, extent and character of any non-focal (e.g., bump) periosteal reaction present.

Skeletal remains were subjected to visual examination of all articular and cortical surfaces-to identify all occurrences of alterations throughout each skeleton, specify the types of bony alterations at each occurrence, and map the distribution of occurrences in each skeleton. In sites where preservation was fragmentary, the sample size (denominator) was determined on the basis of sufficient tibial preservation for assessment, as the tibia is the sentinel bone for recognition of treponemal disease as a population phenomenon (Rothschild \& Rothschild, 1995; 
Table 1.

Texas and North American evidence of non-focal periosteal reaction*.

\begin{tabular}{|c|c|c|c|c|}
\hline Site & Century BP** & \# & Periostitis & Sabre shin \\
\hline Buckeye Knoll (41VT98) Texas & 60 & 37 & 0 & Absent \\
\hline Bird Island (8DI52) Florida & 45 & 19 & 0 & Absent \\
\hline Kamarvik (LeHv-1) NW Territories & 8 & 79 & & Absent \\
\hline Kulaituijavik (LaHw-1) NW Territories & 8 & 22 & 0 & Absent \\
\hline Sadlermuit (KkHh-1) NW Territories & 8 & 25 & 0 & Absent \\
\hline Port Au Chaux, Newfoundland & $34-51$ & 124 & 0 & Absent \\
\hline Glen Williams, Ontario & 9 & 90 & 0 & Absent \\
\hline Maurice Ossuary (BeHa-1), Ontario & 10 & 50 & 0 & Absent \\
\hline Hind (AsdHk-1), Ontario & Archaic & 18 & 0 & Absent \\
\hline Fairty Ossuary, Ontario & 11 & 147 & 0 & Absent \\
\hline Rankin (CK6) Tennessee & Woodland & 21 & 0 & Absent \\
\hline Big Sandy (Hy16), Tennessee & Archaic & 35 & 0 & Absent \\
\hline Oakview Landing (40DR1) Tennessee & Archaic & 56 & 0 & Absent \\
\hline Hatten Mound (23MN275) Missouri & 28 & 23 & 0 & Absent \\
\hline Anderson Minnesota & 30 & 30 & $12(40 \%)$ & Present*** \\
\hline Younge, Michigan & 10 & 23 & $9(39 \%)$ & Present*** \\
\hline Galbreath Mounds (33FR58) Ohio & 22 & 26 & $7(27 \%)$ & Present*** \\
\hline McMurray (15Fa313) Ohio & Woodland & 33 & $7(21 \%)$ & Present*** \\
\hline Sidner Mound (Franklin County) OH & Woodland & 46 & $10(22 \%)$ & Present*** \\
\hline Palmer (8OS2) Florida & 11 & 92 & $28(30 \%)$ & Present*** \\
\hline Windover (Titusville) Florida & 79 & 112 & $30(27 \%)$ & Present*** \\
\hline Grant Mound (8BR56) Florida & $18-24$ & 12 & $3(25 \%)$ & Present*** \\
\hline Olmos Dam, Texas & $11-18$ & 8 & $3(38 \%)$ & Present*** \\
\hline Carrier Mills (11SA86088) Illinois & 63 & 159 & $57(36 \%)$ & Present*** \\
\hline LU-25 (Alabama) & 43 & 89 & $36(40 \%)$ & Present*** \\
\hline Ward (15MCL11) Kentucky & 43 & 203 & $73(36 \%)$ & Present*** \\
\hline Ghost Warrior and Nevada & $10-90$ & 51 & $13(26 \%)$ & Present*** \\
\hline
\end{tabular}

Note: * Derived from Rothschild and Martin, 2005; Rothschild and Rothschild, 1998c, 2000; **BP = before present; *** Without visible surface periosteal reaction.

Rothschild \& Martin, 2006). Periosteal reaction in treponemal disease invariably affects the tibia (Rothschild \& Rothschild, 1995; Rothschild \& Rothschild, 1996; Rothschild et al., 1995a).

\section{Results}

Examination of the skeletons of 37 (number determined on basis of sufficient tibial preservation) individuals from 6000 year bp Texas revealed evidence of isolated bumps and occasional cases of osteomyelitis, but no diffuse periosteal reaction (Table 1) and no sabre shin reaction. This was similar to observations in the Florida 4500 year bp Bird Island (8DI52) site, in which the 19 individuals present were similarly spared.

This sparing phenomenon contrasted with the east Florida 8000 year bp Windover and 1800 - 2400 ybp Grant mound sites and the 1800 - 2000 year bp Texas Olmos Dam site in which periosteal reaction was common (Table 1). Tibial involvement in the east Florida and Olmos Dam sites was invariable bilateral. Disease was predominantly poly-ostotic ( $>3$ bone groups affected). Hand and foot involvement was common and juveniles, commonly affected.

Actually, most of early North Americans manifested the phenomenon observed in the east Florida sites and Olmos Dam, but with other notable exceptions (Table 1). Periosteal reaction was also rare in the northwest territories of Canada, the Atlantic provinces and eastern Ontario and from Archaic Tennessee and Missouri.

\section{Discussion}

\section{Early Texas as a Virgin State for Treponematoses}

Absence of periosteal reaction (unassociated with osteomyelitis and exclusive of isolated bumps) from the 6000 year bp Texas site examined documents a greater degree of population virginity, with respect to exposure to the entities that commonly cause periosteal reaction. Periosteal reaction occurring as a population phenomenon (e.g., more $1 \%$ of population manifesting diffuse involvement of more than one bone) has only a very limited number of etiologies: Treponematoses and hypertrophic osteoarthropathy (McCarty \& Koopman, 1993; Resnick, 2002; Rothschild \& Martin, 1993, 2006; Rothschild \& Rothschild, 2005). While hypertrophic osteoarthropathy (as a complication predominantly of intrathoracic disease) is actually quite rare in unselected populations (Resnick, 2002; Rothschild \& Rothschild, 1998b) and as noted in the populations studied herein, treponemal disease has a unique population signature, if it is present. That population signature is in the form of periosteal reaction, affecting $2 \%-13 \%$ of skeletons with syphilis and $20-40 \%$ of skeletons with yaws or bejel (Rothschild \& Martin, 2005, 2006; Rothschild \& Rothschild, 1995).

The rarity of periosteal reaction in 191 individuals in a zone extending from western Florida to Texas and North to Tennessee and Missouri, and in 619 individuals from Northern and eastern Canada, clearly documents this region as virgin territory or at least that the local Native Americans were not afflicted by 
any known treponematosis in the time periods studied. It also falsifies the speculation (Goodman et al., 1988) that periosteal reaction represents a non-specific stress reaction.

This contrasted with observations in eastern Florida and more recent Texas and outside of the above defined treponematosis-free areas. Periosteal reaction was prominent outside that catchment area (Table 1), in a frequency and pattern indistinguishable from what is seen in yaws (Helfet, 1944; Hudson, 1958; Hunt \& Johnson, 1923; Moss \& Bigelow, 1922; Rothschild \& Rothschild, 1995; Rothschild \& Martin, 2005). This disease is easily distinguished from the more pauci-ostotic syphilis (Chi square $=3.973, p<0.05$ ), in which hand and foot and subadult affliction are so rarely observed in skeletal populations (Rothschild and Rothschild, 1994, 1995a-b); Rothschild et al., 1995a). Other evidence for syphilis (in the form of complete saber shin surface remodeling and unilateral tibial disease) was also lacking. This was also easily distinguished from the more pauci-ostotic bejel, which infrequently affects hands and feet (Hershkovitz et al., 1995; Rothschild \& Rothschild, 1995b). Sabre shin reaction is not found in hypertrophic osteoarthropathy, predominantly a disease of distal diaphyses (Resnick, 2002; Rothschild, 1982; Rothschild \& Martin, 1993). Thyroid acropachy spares the proximal appendicular skeleton, predominantly producing hand and foot bone periosteal reaction (Resnick, 2002; Rothschild, 1982; Rothschild \& Yoon, 1982). Infantile cortical hyperostosis is a disorder afflicting clavicles, scapulae, and ribs (Resnick, 2002). Hypervitaminosis A is predominantly an enthesial disease, and fluorosis produces highly characteristic trabecular alterations (Resnick, 2002; Rothschild \& Martin, 1993; Seawright \& English, 1967).

\section{Possible Reasons for a Treponematosis-Free Zone in Early Texas Native Americans}

Although there is clear evidence for treponematosis in North America, in the form of yaws, it is also clear that a zone existed in which the inhabitants were not afflicted. Given that yaws is a population phenomenon (afflicting essentially the entire population) and given the evidence (e.g., Windover and Ghost warrior) that it had a long history, anteceding the Buckeye Knoll and Bird Island sites, it would appear that these were distinct populations. As yaws is contiguous in distribution in Archaic and Woodland North America, it appears to have arrived with an immigrant population from Asia. The absence of Yaws in specific Canadian and Southern zones suggests that these may have derived from a separate immigration (migration).

This report further demonstrates how paleoepidemiology can be used to identify population distinctiveness in paleopopulations.

\section{References}

Anderson, J. E. (1968). The people of Fairty: An Osteological analysis of an Iroquois ossuary. National Museum of Canada Bulletin, 193, 28-129.

Buikstra, J. E., \& Cook, D. C. (1980). Paleopathology: An American account. Annual Review of Anthropology, 9, 433-470. doi:10.1146/annurev.an.09.100180.002245

Byers, S. N. (1998) The skeletal biology of the lower Mississippi River valley. American Journal of Physical Anthropology, Supplement 26, 116.

Cockburn, E. (1995). Forty years on: Are Aidan Cockburn's theories still valid? In O. Dutour, G. Palfi, J. Berato \& J.-P. Brun (Eds.), L'Origin de la syphilis en Europe avant ou apres 1493 (pp. 23-26). Toulon: Centre Archeologique du Var.

Cook, D. C. (1998) Syphilis? Not quite: Paleoepidemiology in an evo- lutionary context in the Midwest. American Journal of Physical Anthropology, Supplement 26, 70.

Cook, D. C. (1984). Subsistence and health in the lower Illinois valley: Osteological evidence. In M. N. Cohen \& G. J. Armelagos (Eds.), Paleopathology at the origins of agriculture (pp. 235-269). Orlando: Academic Press.

Cook, D. (1976a). The epidemiology of periostitis in prehistoric Illinois. American Journal of Physical Anthropology, 44, 171.

Cook, D. C. (1976b). Pathologic states and disease processes in illinois woodland populations: An epidemiologic approach. Ph.D. Thesis, Chicago: University of Chicago.

Goodman, A. H., Brooke Thomas, R., Swedlund, A. C., \& Armelagos, G. J. (1988). Biocultural perspectives on stress in prehistoric, historical and contemporary population research. Yearbook of Physical Anthropology, 31, 169-202. doi:10.1002/ajpa.1330310509

Helfet, A. J. (1944). Acute manifestations of Yaws of bone and joint. Journal of Bone and Joint Surgery, 26B, 672-685.

Hershkovitz, I., Rothschild, B. M., Wish-Baratz, S., \& Rothschild, C. (1995). Natural variation and differential diagnosis of skeletal changes in Bejel (endemic syphilis). In O. Dutour, G. Palfi, J. Berato \& J.-P. Brun (Eds.), The origin of syphilis in Europe (pp. 81-87). Toulon: Centre Archeologique du Var.

Hudson, E. H. (1958). The treponematoses-or treponematosis? British Journal of Venereal Disease, 34, 22-24.

Hunt, D., \& Johnson, A. L. (1923). Yaws a study based on over 2000 cases treated on American Somoa. United States Naval Bulletin, 18, 559-581.

Hurley, M. F., Scully, O. M., \& McCutcheon, S. W. (1994). Late Viking age and medieval waterford. Excavations 1986-1992. Waterford: Waterford Corporation.

Ishai A., Bikle P. C., \& Ungerleider L. G. (2006). Temporal dynamics of face repetition suppression. Brain Research Bulletin, 70, 289-295. doi:10.1016/j.brainresbull.2006.06.002

Katzenberg, M. A. (1992). Changing diet and health in pre- and protohistoric Ontario. University of Pennsylvania MASCA Research Papers in Science and Archeology, 9, 23-31.

Manchester, K. (1988). Cannington. Journal of Archaeological Science, $15,51$.

McCarty, D. J., \& Koopman, W. J. (1993). Arthritis and allied conditions. Philadelphia: Lea \& Febiger.

Moss, W. L., \& Biegelow, G. H. (1922). Yaws: An analysis of 1046 cases in the Dominican Republic. Bulletin of the Johns Hopkins Hospital, 33, 43-47.

Powell, M. L., \& Cook, D. C. (2005). The myth of syphilis: The natural history of treponematosis in North America. Gainsville: University Press of Florida.

Powell, M. L., \& Eisenberg, L. E. (1998). Syphilis in mound builders' bones: Treponematosis in the prehistoric Southwest. American Journal of Physical Anthropology, Supplement 26, 180.

Power, C. (1992). The spread of syphilis and a possible early case in Waterford. Archaeology of Ireland, 6, 20-21.

Resnick, D. (2002). Diagnosis of bone and joint disorders. Philadelphia: Saunders.

Rose, J. C. (1985). Gone to a better land. Arkansas Archeological Survey Research Series, Fayetteville, 25, 1-216.

Rothschild, B. M. (1982). Rheumatology: A primary care approach. New York: Yorke Medical Press.

Rothschild, B. M., \& Martin, L. D. (1993). Paleopathology: Disease in the fossil record. London: CRC Press.

Rothschild, B. M, \& Martin, L. D. (2006). Skeletal impact of disease. Albuquerque: New Mexico Museum of Natural History Press.

Rothschild, B. M., \& Rogers, R. (2010). Climate and New World periosteal reaction patterns: Implications for migration routes into the Western Hemisphere. Historical Biology, 21, 115-122. doi:10.1080/08912960903281504

Rothschild, B. M., \& Rothschild, C. (2000). Occurrence and transitions among the treponematoses in North America. Chungara, Revista de Antropologia Chilena, 32, 147-155.

Rothschild, B. M., \& Rothschild, C. (1998a). Pseudoscience and treponemal disease in the Western Pacific. Current Anthropology, 40, 69-71. doi:10.1086/515803

Rothschild, B. M., \& Rothschild, C. (1998b). Recognition of hypertrophic osteoarthropathy in skeletal remains. Journal of Rheumatology, 
25, 2221-2227.

Rothschild, B. M., \& Rothschild, C. (1998c). Skeletal examinationbased recognition of treponematoses: A four continent odyssey of denouement, transition and spread. Bulletin de la Memoire Sociéte Anthropologie de Paris, 10, 29-40. doi:10.3406/bmsap.1998.2500

Rothschild, B. M., \& Rothschild, C. (1996). Treponemal disease in the new world. Current Anthropology, 37, 555-561. doi:10.1086/204519

Rothschild, B. M., \& Rothschild, C. (1995a). Distinction des maladies treponemiques: Syphilis, Pian et Bejel a partir des differences de leurs atteintes osseuses respectives. In O. Dutour, G. Palfi, J. Berato \& J.-P. Brun (Eds.), L'Origin de la Syphilis en Europe-Avant ou Apres 1493 (pp. 68-71). Toulon: Centre Archeologique du Var.

Rothschild, B. M., \& Rothschild, C. (1995b). Treponemal disease revisited: Skeletal discriminators for Yaws, Bejel and venereal syphilis. Clinical Infectious Disease, 20, 1402-1408. doi:10.1093/clinids/20.5.1402

Rothschild, C., \& Rothschild, B. M. (1994). Syphilis, Yaws and Bejel: Population distribution in North America. American Journal of Physical Anthropology, 94, 174-175.

Rothschild, B. M., \& Yoon, B. H. (1982). Thyroid acropachy complicated by lymphatic obstruction. Arthritis \& Rheumatism, 25, 588590. doi:10.1002/art.1780250516

Rothschild, B. M., Rothschild, C., \& Hill, M. C. (1995a). Origin and transition of varieties of treponemal disease in the New World. Ame- rican Journal of Physical Anthropology, Supplement 20, 185.

Rothschild, B. M., Hershkovitz, I., \& Rothschild, C. (1995b). Origin of yaws in the Pleistocene. Nature, 378, 343-344. doi:10.1038/378343b0

Sanford, M. K., Bogdan, G., \& Kissling, G. E. (1998) Treponematosis in the prehistoric Caribbean, North Carolina coast and Kentucky: Diagnostic considerations. American Journal of Physical Anthropology, Supplement 26, 194.

Seawright, A. A., \& English, P. B. (1967). Hypervitaminosis A and deforming cervical spondylosis of the cat. Journal of Comparative Pathology, 77, 29-43. doi:10.1016/S0021-9975(67)80004-5

Spirov, G. (1991). Endemic syphilis in Bulgaria. Genitourinary Medicine, 67, 428-435.

Stirland, A. (1995). Evidence for pre-Columbian treponematosis in Medieval Europe. In O. Dutour, G. Palfi, J. Berato \& J.-P. Brun (Eds.), L'Origin de la Syphilis en Europe-Avant ou Apres 1493 (pp. 109-115). Toulon: Centre Archeologique du Var.

Spodick, D. H. (1983). Q-wave infarction versus S-T infarction. Nonspecificity of electrocardiographic criteria for differentiating transmural and nontransrnural lesions. American Journal of Cardiology, 51, 913-915. doi:10.1016/S0002-9149(83)80160-X 